\title{
Germination and Seedling Emergence of Ammannia coccinea as Influenced by Environmental Factors
}

\begin{abstract}
Xiangri Shen ${ }^{1}$, Jong-Yeong Pyon ${ }^{1}$ and Do-Soon Kim ${ }^{2 *}$
ABSTRACT Petri dish and pot experiments were conducted to investigate germination and seedling emergence of Ammannia coccinea as influenced by environmental factors. The best germination of $A$. coccinea was obtained at $35 / 30^{\circ} \mathrm{C}$ of temperature and 0 bar of osmotic potential, while no germination at temperatures of $\leq 15^{\circ} \mathrm{C}$ and $\geq 40^{\circ} \mathrm{C}$, osmotic potentials of $\leq-2.0$ bar, or dark condition. The best seedling emergence was observed at $35 / 30^{\circ} \mathrm{C}$, at which the first emergence of $A$. coccinea was observed at 7 days after sowing (DAS) with its maximum emergence reached at 10 DAS. No seedling emergence was observed at $15 / 10^{\circ} \mathrm{C}$ with significant reduction at $40 / 35^{\circ} \mathrm{C}$. Seedling emergence decreased with increasing soil depth, resulting in no seedling emergence at $\geq 3 \mathrm{~cm}$. The Gompertz model well described the cumulative germination and seedling emergence of A. coccinea with time. Germination influenced by osmotic potential and seedling emergence influenced by soil burial depth were well described by the logistic model. Overall results indicate that $A$. coccinea is photoblastic and requires temperatures greater than $15^{\circ} \mathrm{C}$, osmotic potential greater than -2.0 bar, and soil burial depth shallower than $3 \mathrm{~cm}$ for its germination and seedling emergence, which were faster than M. vaginalis but slower than E. crus-galli.
\end{abstract}

Key words: Ammannia coccinea; germination; Gompertz model; osmotic potential; seedling emergence; soil depth, temperature.

\section{INTRODUCTION}

Ammannia species belong to Lythreceae family and include A. auriculata, A. baccifera, A. coccinea, A. multiflora, etc. Among Ammannia species, $A$. multiflora is one of major problem weeds in paddy field in Southeast Asia, particularly in Japan, Taiwan, and South China. Ammannia coccinea Rottb., purple ammania, is similar to A. multiflora in its morphology, but it can be easily distinguished

\footnotetext{
${ }^{1}$ Department of Crop Science, Chungnam National University, Yuseong 305-764, Korea.

${ }^{2}$ Department of Plant Science, Seoul National University, Seoul 151-921, Korea.

* 연락저자(Corresponding author) : Phone)+82-2-880-4542, Fax)+82-2-873-2056; Email) dosoonkim@snu.ac.kr
} 
by leaf shape. Ammannia coccinea has linearlanceolate leaves, while $A$. multiflora has lanceolate ones, which are wider than those of A. coccinea. Chromosome number of $A$. coccinea is $\mathrm{n}=33$, while that of $A$. multiflora is $\mathrm{n}=9$ (Graham and Cavalcanti 2001). Ammannia coccinea is native to North America, typically found in wet meadows, open fields, river and stream banks, floodplains, ponds, lakes and marshes, and occurs in greatest concentrations primarily in northeastern USA and Canada (Hight and Drea 1991). As an annual invasive broadleaf weed, A. coccinea aggressively invades into wetlands, eliminating native plants (Panigrahi 1980). When $A$. coccinea establishes dense stands, it is able to displace native species (Hanna 1989). Ammannia coccinea was introduced into Japan and other Asian countries in 1950s, in wetland and paddy rice fields. In paddy rice field, it is regarded as an important weed, particularly in Japan (Shibayama 2001), but its abundance in rice fields appears to be less than that of $A$. multiflora. In Korea, A. coccinea was firstly found in Changwon and Yeonggwang in 1981 (NIER 2001; RDA 2005), much later than the first appearance of A. multiflora reported in 1966. Recently, A. coccinea was also found in a paddy field in Daejeon, Korea in 2002 (Shen et al. 2003).

Some efforts have been made to investigate ecophysiological characteristics of Ammannia species in its germination and seedling emergence. Nakayama and Takabayashi (1987) reported high germination of air-dried seed of $A$. coccinea by $94.7 \%$ and no germination of $A$. coccinea and $A$. multiflora under dark condition, indicating that they are photoblastic. Germination of A. multiflora peaked at $32 / 28^{\circ} \mathrm{C}$ and required prolonged period for its germination at $21 / 17^{\circ} \mathrm{C}$ (day/night). For the first seedling emergence of $A$. multiflora, about 10 and 3 days were required at $21 / 17$ and $32 / 28^{\circ} \mathrm{C}$ (day/night), respectively, under flooded condition (Chiang and Chiang 2004). However, most of studies have focused on A. multiflora and not many studies have been done to investigate eco-physiological characteristics of $A$. coccinea as a paddy rice weed. In weed management, it is important to understand early establishment of weeds, which will provide us practical advice for weed control. Little information is available, particularly about germination and seedling emergence of $A$. coccinea.

Therefore, this study was conducted to understand eco-physiological characteristics of $A$. coccinea particularly on its germination and seedling emergence as influenced by environmental factors such as temperature, light, water potential and soil burial depth.

\section{MATERIALS AND METHODS}

\section{Germination tests}

Germination of $A$. coccinea in comparison with other paddy weeds

Petri dish test was conducted to compare germination of $A$. coccinea with other paddy weeds, Echinochloa crus-galli and Monochloa vaginalis, in a growth chamber (HB-303D, Hanbaek Co., Korea). Seeds used in this test were collected in October 2005. One hundred seeds of $A$. coccinea, E. crus-galli and $M$. vaginalis were placed on water-saturated filter paper in Petri dishes. Petri dishes were placed for 15 days in optimum germination conditions in the growth chamber maintained at $30 / 25^{\circ} \mathrm{C}$ (day/ night) with 5 replicates. Germinated seeds were recorded and removed every other day until 14 days after sowing (DAS). Seeds were considered germinated when the radicle had extended at least $1 \mathrm{~mm}$. 


\section{Effects of temperature}

One hundred seeds were placed on water-saturated filter paper in Petri dishes, and the dishes were placed in the growth chambers maintained at constant temperatures of $15,20,25,30,35$ and $40^{\circ} \mathrm{C}$ and alternating temperatures of 20/15, 25/20, 30/25, $35 / 30$ and $40 / 35^{\circ} \mathrm{C}$ (day/night). Each temperature treatment had 6 replicates. Germination was recorded daily.

\section{Effects of light}

Fifty seeds of $A$. coccinea were placed on watersaturated filter papers in Petri dishes. Petri dishes were placed in light $\left(220 \pm 20 \mu \mathrm{E} \mathrm{s}^{-1} \mathrm{~m}^{-2}\right.$ PAR $)$ and dark conditions in the growth chamber maintained at $30^{\circ} \mathrm{C}$ with 4 replicates. Petri dishes in dark were subsequently covered with aluminum foil to prevent from light exposure. Germination was recorded every other day.

\section{Effects of osmotic potential}

Aqueous solutions of polyethylene glycol 6000 MW (PEG 6000) and distilled water were used for producing a range of osmotic potentials $(0,-0.25$, $-0.5,-0.75,-1.0,-2.0,-3.0,-4.0$ and -5.0 bar). The solutions were originally prepared according to the equation by Michel and Kaufmann (1973) and verified using a micro-voltmeter (HR33-T, Wescor Inc., USA). In each Petri dish, 50 seeds of $A$. coccinea, E. crus-galli and Aneilemma keisak were placed on water-saturated filter paper in Petri dishes, then sealed with parafilm to avoid moisture loss and placed in the growth camber at $35 / 30^{\circ} \mathrm{C}$ with 5 replicates. Germination was recorded daily.

\section{Seedling emergence tests}

Seedling emergence of A. coccinea in comparison with other paddy weeds

Each one hundred seeds of A. coccinea, $M$. vaginalis and E. crus-galli were sown in Wagner pots, and covered with sandy loam soil to adjust 0.5 $\mathrm{cm}$ soil depth. The pots were placed in the growth chamber at $35 / 30^{\circ} \mathrm{C}$ (day/night) in a completely randomized design with 5 replicates. Seedling emergence was recorded daily until 14 DAS.

\section{Effects of temperature and soil water potential}

Bulk soil samples to a depth of $5 \mathrm{~cm}$ were collected from the paddy field, air-dried, crushed, and passed through a $2 \mathrm{~mm}$ sieve. Air-dried soil were placed in Wagner pots and different amount of distilled water was added to obtain -0.03 bar and -0.98 bar of water potentials, which were maintained by continuous sub-irrigation and top irrigation, respectively. One hundred seeds of A. coccinea were sown in Wagner pots to a depth of $0.5 \mathrm{~cm}$. The pots were placed in the growth chambers maintained at different temperature ranges : 15/10, $20 / 15,25 / 20,30 / 25,35 / 30$ and $40 / 35^{\circ} \mathrm{C}$ (day/night) in a randomized block design with 4 replicates. Seedling emergence was recorded daily until 14 DAS.

\section{Effect of soil burial depth}

One hundred seeds of $A$. coccinea, M. vaginalis and E. crus-galli were sown and covered with different amounts of soil to adjust the soil depths to be $0,1,2,3,4,5$, and $7 \mathrm{~cm}$ in Wagner pots. The pots were placed in the glasshouse maintained at $25 \pm 3{ }^{\circ} \mathrm{C}$ in a randomized block design with 5 replicates. Appropriate soil water content (osmotic potential of -0.03 bar) was maintained by regular irrigation. Seedling emergence was recorded daily until 24 DAS.

\section{Statistical analysis}

All measurements were initially subjected to ANOVA. Non-linear regression was used to fit the 
Gompertz (1825) and logistic models to cumulative germination or seedling emergence with time, seedling emergence with increasing soil burial depth, and seedling emergence with temperature, respectively. To describe cumulative germination or seedling emergence with time after sowing, Gompertz model has widely been used by many weed scientists (e.g. Cussans et al. 1996; Kim et al. 2006a). So, the following Gompertz model was used in this study to describe germination and seedling emergence of $A$. coccinea with time,

$$
y=\frac{C}{e^{e^{-B(T-M)}}}
$$

where $y$ is the cumulative germination or emergence at days (T) after sowing, $C$ is the maximum germination or emergence, $B$ is the rate of increase of germination or emergence once it is initiated, $M$ is a time lag to reach $50 \%$ of the maximum cumulative germination or emergence.

The logistic model has also widely been used to describe many biological phenomena, such as plant growth and herbicide dose-response (e.g. Streibig 1980; Kim et al. 2002; Kim et al. 2006b). In this study, the logistic model was used to describe germination influenced by osmotic potential and seedling emergence influenced by soil depth.

$$
z=\frac{C}{\left(1+\left(X / e^{M}\right)^{-B}\right)}
$$

where $\mathrm{z}$ is the percent germination or emergence at different osmotic potentials or soil depths $(\mathrm{X}), \mathrm{C}$ is the maximum germination or emergence, $B$ is the rate of increase of germination or emergence, $M$ is an osmotic potential or soil depth to reach $50 \%$ of the maximum germination or emergence.

All statistical analyses were carried out using Genstat 5 (Genstat Committee 1997).

\section{RESULTS AND DISCUSSION}

\section{Germination of $A$. coccinea}

Germination of A. coccinea in comparison with other paddy weeds

The first germination of $A$. coccinea at $30 / 25^{\circ} \mathrm{C}$ (day/night) was observed at 3 DAS, the same as $E$. crus-galli, while that of $M$. vaginalis was at 7 DAS (Fig. 1). The maximum percent germination of $A$. coccinea was $46.5 \%$ achieved at 13 DAS, while those of E. crus-galli and M. vaginalis were $85.7 \%$ and $57 \%$ at 8 and 14 DAS, respectively. Non-linear regression conducted by fitting the Gompertz model estimated maximum germination to be $45.8,58.7$ and $86 \%$ for A. coccinea, M. vaginalis and E. crus-galli, respectively, indicating that $A$. coccinea has the lowest germination potential. The days required to achieve $50 \%$ of the maximum germination were estimated to be 5.6, 9.8 and 4.0 days for A. coccinea, M. vaginalis and E. crus-galli, respectively, indicating that $A$. coccinea can germinate more quickly when compared with $M$. vaginalis.

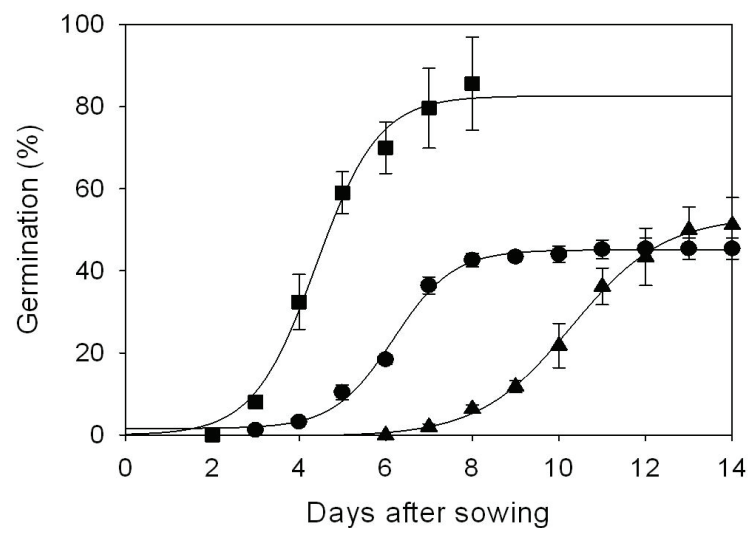

Fig. 1. Germination of A. coccinea $(\bullet)$, M. vaginalis $(\boldsymbol{\Delta})$ and E. crus-galli $(\mathbf{\square})$ at $30 / 25^{\circ} \mathrm{C}$. The continuous lines are fitted germination using the Gompertz model (equation 1) and the parameters estimates; $C$ $=45.8,58.7$, and 86.0, $B=0.862,0.529$, and 0.874, and $M=5.59,9.80$, and 3.97 for $A$. coccinea, $M$. vaginalis, and E. crus-galli, respectively. The vertical bar indicates standard deviation of 5 replicates. 
Effects of temperature on A. coccinea germination

At constant temperature conditions, the first germination of A. coccinea was observed at 17,8 , 6 and $7 \mathrm{DAS}$ at $20,25,30$ and $35^{\circ} \mathrm{C}$, respectively (Fig. 2). The maximum germination was 2.8, 29.2, 38.4 and $28.8 \%$ at $20,25,30$ and $35^{\circ} \mathrm{C}$, achieved at $17,18,15,16$ DAS, respectively. However, no germination of $A$. coccinea was observed at 15 and $40^{\circ} \mathrm{C}$. Therefore, these findings indicate that the constant temperature of $30^{\circ} \mathrm{C}$ may be the optimum temperature for the germination of A. coccinea, and 15 and $40^{\circ} \mathrm{C}$ may be the lower and upper limits for the germination of A. coccinea. The Gompertz model also estimated the greatest germination of $38.5 \%$ at $30^{\circ} \mathrm{C}$, followed by $32.3,30.0$ and $3.0 \%$ at 35,25 and $20^{\circ} \mathrm{C}$, respectively. The days required for $50 \%$ of the maximum germination was shortest at $30^{\circ} \mathrm{C}, 8.25$ days, followed by $10.1,11.3$ and 16.3 days at 35,25 and $20^{\circ} \mathrm{C}$, respectively.

At alternating temperature conditions, the first germination of A. coccinea was observed at 8, 6, 3,

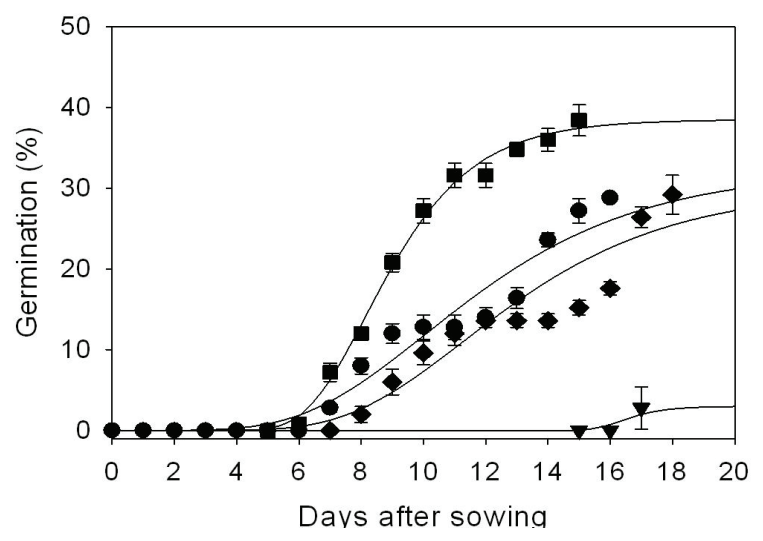

Fig. 2. Germination of $A$. coccinea at various constant temperatures. The continuous lines are fitted germination calculated using the Gompertz model (equation 1) and the parameter estimates; $C=$ $32.3,38.5,30.0$, and 3.01, $B=0.26,0.52,0.27$, and $1.24, M=10.05,8.15,11.28$ and 16.27 at 35 ${ }^{\circ} \mathrm{C}(\bullet), 30^{\circ} \mathrm{C}(\boldsymbol{\bullet}), 25^{\circ} \mathrm{C}(\bullet)$ and $20^{\circ} \mathrm{C}(\boldsymbol{\nabla})$, respectively. No germination was observed at 15 and $40^{\circ} \mathrm{C}$. The vertical bar indicates standard deviation of 6 replicates.

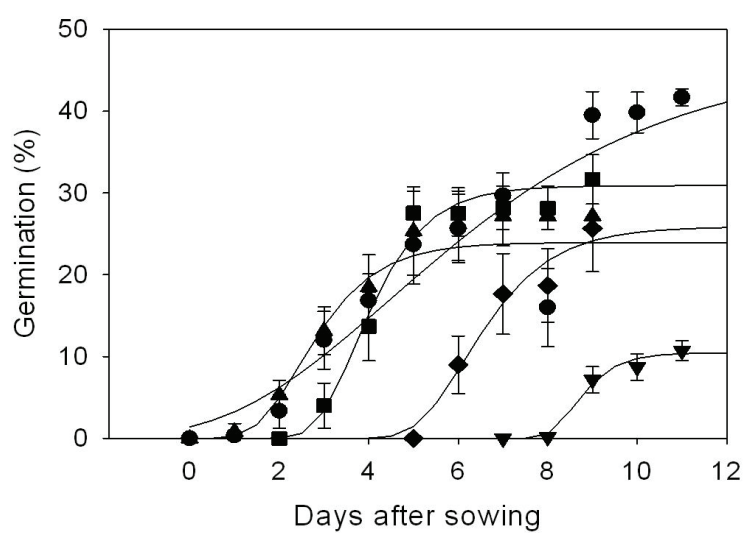

Fig. 3. Germination of $A$. coccinea at various alternating temperatures. The continuous lines are fitted germination calculated using the Gompertz model (equation 1) and the parameter estimates; $C=$ $10.45,25,87,30.89,46.52$, and $23.95, B=1.89$, $0.93,1.14,0.28$ and $1.04, M=8.57,6.14,3.70$, 4.51 and 2.44 at $20 / 15^{\circ} \mathrm{C}(\boldsymbol{\nabla}), 25 / 20^{\circ} \mathrm{C}(\boldsymbol{\nabla})$,

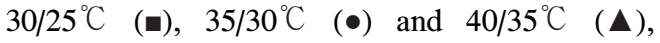
respectively. The vertical bar indicates standard deviation of 6 replicates.

1 and 1 DAS at 20/15, 25/20,30/25, 35/30 and $40 / 35^{\circ} \mathrm{C}$, respectively (Fig. 3). The maximum germination was $10.7,25.7,31.7,41.7$ and $27.2 \%$ at $20 / 15,25 / 20,30 / 25,35 / 30$ and $40 / 35^{\circ} \mathrm{C}$, achieved at $11,9,9,11$ and $7 \mathrm{DAS}$, respectively. These findings indicate that the alternating temperature of $35 / 30^{\circ} \mathrm{C}$ may be the optimum temperature for the germination of A. coccinea. The Gompertz model also estimated the greatest germination of $46.5 \%$ at $35 / 30^{\circ} \mathrm{C}$, followed by $30.9,25.9,24.0$ and $10.5 \%$ at $30 / 25,25 / 20,40 / 35$ and $20 / 15^{\circ} \mathrm{C}$, respectively.

The days required for $50 \%$ of the maximum germination was 2.4 days at $40 / 35^{\circ} \mathrm{C}$, shortest, followed by 3.7, 4.5, 6.1 and 8.6 days at 30/25, $35 / 30,25 / 20$ and $20 / 15^{\circ} \mathrm{C}$, respectively. Comparison of germination at constant and alternating temperature conditions revealed that $A$. coccinea germinated better, particularly in terms of speed, at alternating temperatures than constant temperatures, and optimum, lower limit and upper limit temperatures were 
$35 / 30,15$, and $40^{\circ} \mathrm{C}$, respectively.

\section{Effects of light on A. coccinea germination}

To investigate the effect of light on the germination of $A$. coccinea, germination test was conducted under light and dark conditions separately. A. coccinea began to germinate at 3 DAS under light condition and reached its maximum germina- tion of $48.5 \%$ at 9 DAS while no germination of $A$. coccinea was observed throughout the whole test periods under dark condition (Fig. 4). Therefore, this result clearly indicated that $A$. coccinea seed requires light for its germination, so called photoblastic seed.

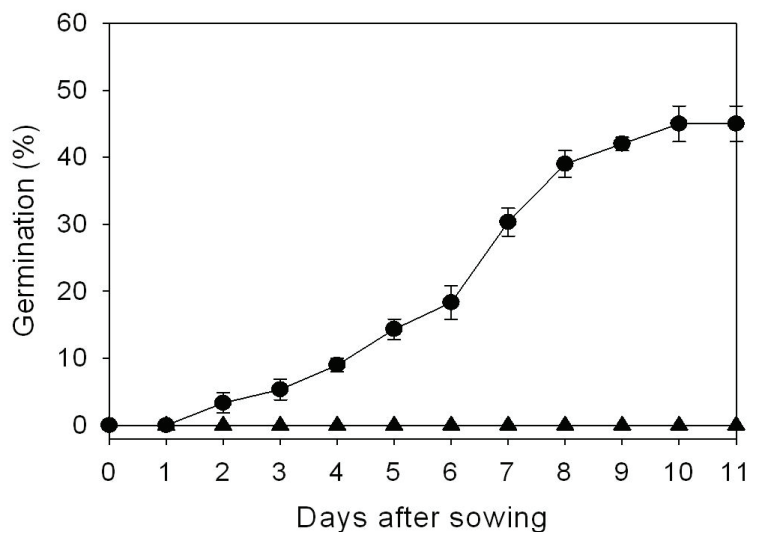

Fig. 4. Germination of $A$. coccinea under light $(\bullet)$ and dark $(\boldsymbol{\Delta})$ conditions. The vertical bar indicates standard deviation of 4 replicates.

Effects of osmotic potential on A. coccinea germination

The seed germination was decreased with decreasing osmotic potential (Fig. 5). The greatest germination of $A$. coccinea was $32.9 \%$ observed at the osmotic potential of 0 bar, while no germination observed at osmotic potentials of $\leq-2.0$ bar (Fig. 5). Similar tendency to increase germination with increasing osmotic potential was also observed in A. keisak and E. crus-galli in this experiment. The lowest osmotic potentials allowing germination were $-1.0,-1.0$ and 3.0 bar for $A$. coccinea, $A$. keisak and E. crus-galli, respectively. This finding

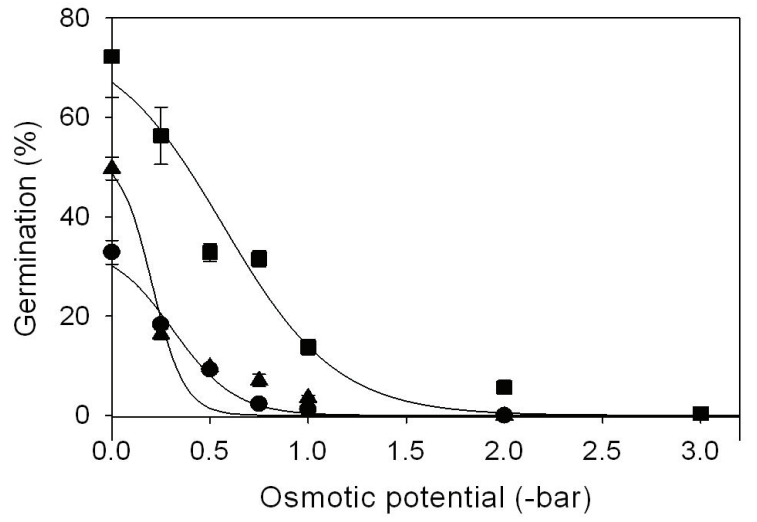

Fig. 5. Germination of $A$. coccinea $(\bullet)$, A. keisak $(\mathbf{\Delta})$ and E. crus-galli (घ) as affected by osmotic potential. The continuous lines are fitted germination calculated using the logistic model (equation 2) and the parameter estimates; $C=34.39,52.72$, and 76.46, $B=-6.32,12.20$, and $3.47, M=-0.32,-0.21$, and -0.57 for A. coccinea, A. keisak and E. crus-galli, respectively. The vertical bar indicates standard deviation of 5 replicates.

thus indicates that $A$. coccinea and $A$. keisak have similar water requirement for their germination and less tolerant to water stress than E. crus-galli. The logistic model fitted to observed data by non-linear regression estimated water potential required to inhibit germination by $50 \%$ of the maximum germinations of $A$. coccinea, A. keisak and $E$. crus-galli were $-0.3,-0.2$ and -0.6 bar, respectively, indicating that the germination of A. coccinea is slightly less affected by osmotic potential than $A$. keisak but more than E. crus-galli.

\section{Seedling emergence of $A$. coccinea}

Seedling emergence of $A$. coccinea in comparison with other paddy weeds

To evaluate the seedling emergence of $A$. coccinea in comparison with E. crus-galli and M. vaginalis, seedling emergence test was conducted at $0.5 \mathrm{~cm}$ of soil depth and at $35 / 30^{\circ} \mathrm{C}$ of temperature in the growth chamber. The first seedling emergence of $A$. coccinea was observed at 7 DAS and reached its maximum seedling emergence of $27.9 \%$ at 10 DAS 


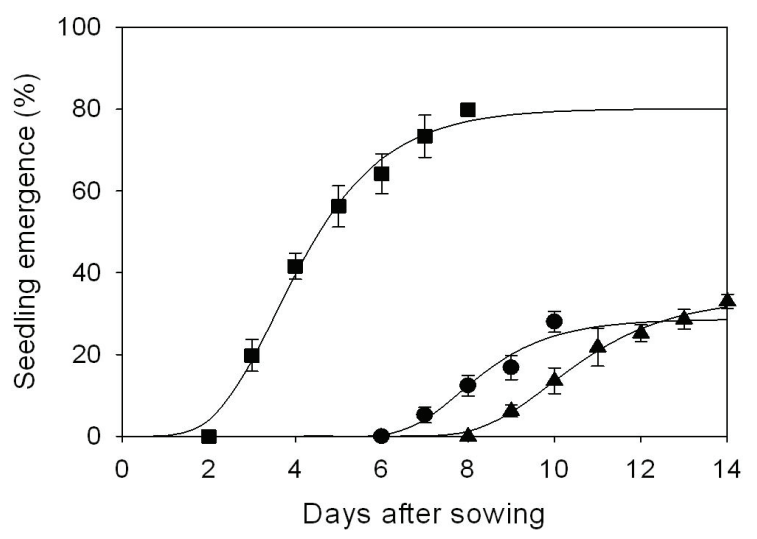

Fig. 6. Seedling emergence of $A$. coccinea $(\bullet), M$. vaginalis $(\boldsymbol{\Delta})$ and E. crus-galli $(\mathbf{\square})$ at $35 / 30^{\circ} \mathrm{C}$. The continuous lines are fitted germination calculated using the Gompertz model (equation 1) and the parameter estimates; $C=28.67$, 33.96, and $80.14, B=0.84,0.64$, and $0.73, M$ $=7.79,9.87$, and 3.52 for $A$. coccinea, $M$. vaginalis, and $E$. crus-galli, respectively. The vertical bar indicates standard deviation of 5 replicates.

(Fig. 6). By comparison, the first emergences of $E$. crus-galli and M. vaginalis were observed at 3 and 9 DAS and their maximum seedling emergences were $79.8 \%$ and $33 \%$ at 9 and 14 DAS, respectively. The Gompertz model fitted to observed seedling emergence by non-linear regression. The model estimated the maximum emergence of 28.7, 34.0 and $80.1 \%$ for A. coccinea, M. vaginalis and $E$. crus-galli, respectively. Estimated days required for $50 \%$ of the maximum seedling emergence were 7.9, 9.9 and 3.5 DAS for A. coccinea, M. vaginalis and E. crus-galli, respectively, showing similar trend to their germination (Fig. 1), indicating that $A$. coccinea can emerge more quickly than $M$. vaginalis but slowly than E. crus-galli.

Effects of temperature and soil water potential on A. coccinea seedling emergence

As the germination of $A$. coccinea was significantly affected by both osmotic potential and temperature (Fig. 5), emergence test was conducted under two

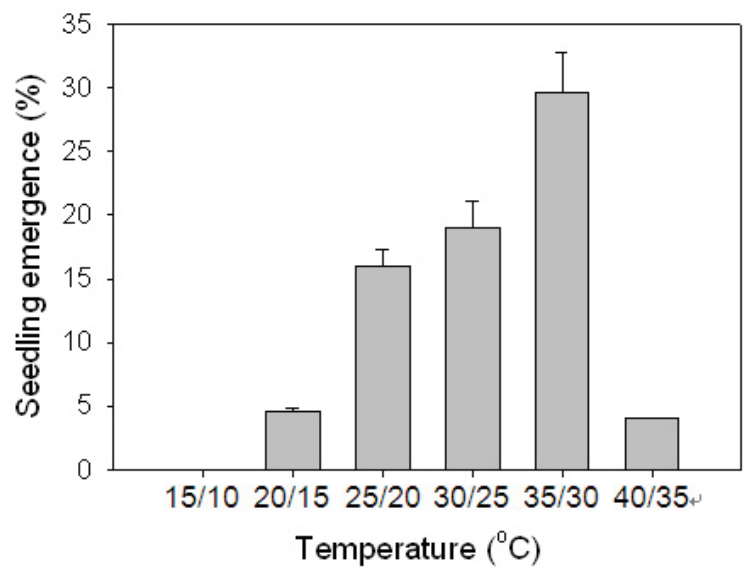

Fig. 7. Seedling emergence of $A$. coccinea as influenced by air temperatures at soil water potentials of -0.03 and -0.97 bar. The continuous lines are fitted seedling emergence calculated using the inverse quadratic model (equation 2) and the parameter estimates; $\mathrm{a}=-4.04$ and $-2.64, \mathrm{~b}=$ 3.564 and $1.425, \mathrm{c}=-0.084$ and $-0.0336, \mathrm{~d}=$ -0.06023 and -0.06109 , e $=0.0009307$ and 0.0009597 for -0.03 and -0.97 bar, respectively. The vertical bar indicates standard deviation of 4 replicates.

contrasting soil water condition with varying temperatures. The seedling emergence of $A$. coccinea was also significantly affected by water potential and temperature with significantly greater emergence at -0.03 bar than -0.98 bar, and the best seedling emergence of $34 \%$, no emergence, and significantly reduced emergence at $35 / 30,15 / 10$, and $40 / 35^{\circ} \mathrm{C}$, respectively (Fig. 7).

Effect of soil burial depth on A. coccinea seedling emergence

To evaluate the effects of soil burial depth on the seedling emergence of $A$. coccinea, the seeds of $A$. coccinea were sown at various soil burial depths. Seedling emergences of all the tested species significantly decreased with increasing soil burial depth although seedling emergences of $M$. vaginalis and E. crus-galli at $0 \mathrm{~cm}$ soil depth were slightly lower than those at $1 \mathrm{~cm}$ soil depth (Fig. 8). The 


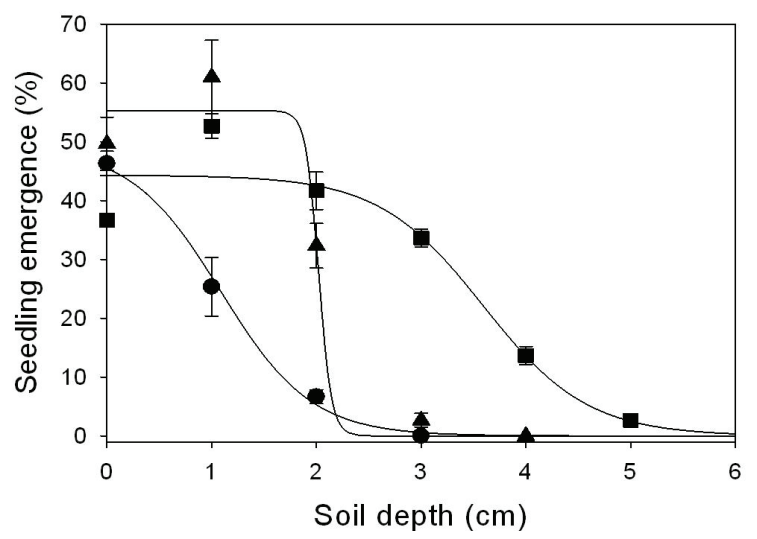

Fig. 8. Seedling emergence of $A$. coccinea $(\bullet), M$. vaginalis $(\mathbf{\Delta})$ and E. crus-galli $(\mathbf{\square})$ at various soil burial depths. The continuous lines are fitted emergence calculated using the logistic model (equation 2) and the parameter estimate; $C=49.13,55.33$, and 44.30, $B=-2.32,-16.23$, and $-2.00, M=1.09,2.02$, and 3.59 for $A$. coccinea, M. vaginalis and E. crus-galli, respectively. The vertical bar indicates standard deviation of 5 replicates.

greatest seedling emergence of $A$. coccinea, $46.4 \%$, was recorded at $0 \mathrm{~cm}$ soil depth, which was significantly greater than those at other depths. The maximum soil depth allowing seedling emergence was $2 \mathrm{~cm}$ for $A$. coccinea, while those for $M$. vaginalis and E. crus-galli were $3 \mathrm{~cm}$ and $5 \mathrm{~cm}$, respectively. Plotting the observed seedling emergence data against soil depth suggested that seedling emergences with increasing soil depth decrease logistically. The logistic model fitted to the observed emergence data estimated $49.1 \%, 55.3 \%$ and $44.3 \%$ of A. coccinea, M. vaginalis and E. crus-galli, respectively. The soil depth required to inhibit $50 \%$ of the maximum seedling emergence was smallest for $A$. coccinea, $1.1 \mathrm{~cm}$, followed by 2.0 and 3.6 $\mathrm{cm}$ of $M$. vaginalis and E. crus-galli, respectively. This finding thus demonstrates that seedling emergence of $A$. coccinea is most significantly affected by soil depth, while E. crus-galli is least affected.

\section{Implication of characteristics of $A$. coccinea} germination and seedling emergence

Ammannia coccinea germinated and emerged faster than $M$. vaginalis but slower than E. crus-galli. Its germination and seedling emergence were best at $35 / 30^{\circ} \mathrm{C}$, while no germination and seedling emergence at both $\leq 15^{\circ} \mathrm{C}$ and $\geq 40^{\circ} \mathrm{C}$ and $15 / 10^{\circ} \mathrm{C}$, respectively. The optimum temperature of $35 / 30^{\circ} \mathrm{C}$ for $A$. coccinea germination is similar to that of $A$. multiflora, whose germination was peaked at $32 / 28$ ${ }^{\circ} \mathrm{C}$ (Chiang and Chiang 2004). The best germination observed at 0 bar of osmotic potential with significant decrease in its germination with decreasing osmotic potential and greater seedling emergence at -0.03 bar than -0.98 bar indicate that germination and seedling emergence of $A$. coccinea require sufficient amount of water. Light and soil burial depth also significantly affected its germination and seedling emergence. No germination observed under dark condition and no seedling emergence at $>3 \mathrm{~cm}$ of soil depth indicate that $A$. coccinea is photoblastic (Nakayama and Takabayashi 1987) and the significant effect of soil burial depth is related to light penetration into soil. Much lower germination and seedling emergence of $A$. coccinea in this study, always less than $50 \%$, than $94.7 \%$ from the study of Nakayama and Takabayashi (1987) suggests that ungerminated seeds in this study may be dormant or immature.

No germination and seedling emergence of $A$. coccinea at $15^{\circ} \mathrm{C}$ and $15 / 10^{\circ} \mathrm{C}$, respectively, implies that $15^{\circ} \mathrm{C}$ is a kind of lowest temperature threshold which does not allow A. coccinea to germinate or emerge, so that it can be regarded as a base temperature to calculate soil degree days. Soil degree days, or heat accumulation units, are used to measure or predict the effect of temperature on biological processes or events (Baskerville and Emin 1969). In particular, soil degree days are now commonly used to predict seedling emergence of 
crop and weed in field condition (e.g. Ekeleme et al. 2004). Therefore, for temperatures greater than $15^{\circ} \mathrm{C}$ can be accumulated and used to predict seedling emergence of $A$. coccinea in field condition.

Empirical models such as Gompertz, logistic, and inverse quadratic models well described the seedling emergence expressed as the time course of cumulative germination or seedling emergence, the effects of osmotic potential and soil burial depth, and seedling emergence influenced by temperature, respectively. Prostko et al. (1997) and Kim et al. (2006a) also used the logistic model to describe the relationship between seedling emergence and soil burial depth. Kim et al. (2006a) incorporated such relationship modeled with the logistic model into the Gompertz model. Therefore, it may also be possible to incorporate the modeled effects of osmotic potential, temperature and soil burial depth in our study into the Gompertz model. Although the Gompertz model was used to describe seedling emergence of $A$. coccinea, it can be used to predict seedling emergence of $A$. coccinea in a practical field condition by employing the concept of soil degree days. Prediction of seedling emergence based on data generated from paddy fields is more practically helpful for decision-making of weed management. As this study was conducted in controlled environments to investigate the effects of various environmental conditions on germination and seedling emergence of $A$. coccinea, further work is required in a practical paddy field condition. Field study may provide us with practical information on seedling emergence and early establishment of $A$. coccinea in a situation where rice grows.

\section{요 약}

다양한 환경조건에서 미국좀부처꽃의 발아 및 출
아 특성을 평가하기 위하여 식물생장상에서 페트리 디쉬와 포트 실험을 수행하였다. 미국좀부처꽃은 $35 / 30^{\circ} \mathrm{C}$ 와 $0 \mathrm{bar}$ 의 삼투포텐셜 조건에서 발아가 가장 잘되었으나 온도가 $15^{\circ} \mathrm{C}$ 이하나 $40^{\circ} \mathrm{C}$ 이상, 삼투포 텐셜이 -2.0 bar 이하와 암조건에서 발아되지 않았다. 출아의 최적온도는 $35 / 30^{\circ} \mathrm{C}$ 로 판단되며 이 조건에서 파종 후 7 일차에 출아가 개시되어 10 일차에 최대 출 아율에 도달하였으며, 온도가 $15 / 10^{\circ} \mathrm{C}$ 이하나 $40 / 35$ ${ }^{\circ} \mathrm{C}$ 이상 조건에서는 출아가 안 되거나 현저히 감소하 였다. 파종심도의 증가에 따라 출아율은 현저히 감소 하여 $3 \mathrm{~cm}$ 이상의 파종심도에서는 출아하지 않았다. 비선형회귀분석을 한 결과 파종 후 시간의 경과에 따 른 미국좀부처꽃의 누적 발아 및 출아는 Gompertz 모델로 잘 설명되었으며 삼투포텐셜에 따른 발아와 파종심도에 따른 출아는 logistic 모델로 잘 설명되었 다. 결론적으로 미국좀부처꽃은 광발아성으로 발아 및 출아 가능 온도는 $15^{\circ} \mathrm{C}$ 이상, 삼투포텐셜은 -2.0 bar 이상, 토양심도는 $3 \mathrm{~cm}$ 이하임을 본 연구를 통하 여 확인하였다.

\section{LITERATURE CITED}

Baskerville, G. L., and D. Emin. 1969. Rapid estimation of heat accumulation from maximum and minimum temperature. Ecol. 50:514-517.

Chiang, Y. J., and M. Y. Chiang. 2004. Influence of temperature regimes and butachlor on the emergence and seedling growth of eight paddy weeds. Plant Prot. Bull. 46:345-356.

Cussans, G. W., S. Radonius, P. Brain and S. Cumbenworth. 1996. Effects of depth of burial and soil aggregate of Alopecurus myosuroides, Galium aparine, Stelaria media and wheat. Weed Res. 36:133-141.

Ekeleme, F., F. Forcella, D. W. Archer, D. Chikoye and I. O. Akobundu. 2004. Simulation of shoot emergence pattern of congograss (Imperata cylindrica) in the humid tropics. Weed Sci. 52: 
961-967.

Genstat 5 Committee. 1997. Genstat 5 Release 4. 1 : Reference Manual Supplement to Genstat 5 Committee (1993) Genstat 5 Reference Manual Release 3. Oxford, UK : Numerical Algorithms Group.

Gompertz, B. 1825. On the nature of the functions expressive of the law of human mortality, and on a new mode of determining the value of life contingencies. Philos. Trans. 115:513-585.

Graham, S. A., and T. B. Cavalcanti. 2001. New chromosome counts in the Lythraceae and a review of chromosome numbers in the family. System Bot. 26:445-458.

Hanna, J. 1989. Purple invader. Seasons 29:20-22, 36.

Hight, S. D., and J. Drea. 1991. Prospects for a classical biological control project against purple loosestrife. Nat. Areas J. 11:151-157.

Kim, D. S., P. Brain, E. J. P. Marshall and J. C. Caseley. 2002. Modelling herbicide dose and weed density effects on crop : weed competition. Weed Res. 42:1-13.

Kim, D. S., Y. W. Kwon and B. W. Lee. 2006a. Mathematical description of seedling emergence of rice and Echinochloa species as influenced by soil burial depth. Kor. J. Crop Sci. 51: 362-368.

Kim, D. S., E. J. P. Marshall, J. C. Caseley and P. Brain. 2006b. Modelling interactions between herbicide and nitrogen fertilizer in terms of weed response. Weed Res. 46:480-491.
Michel, B. E., and M. R. Kaufmann. 1973. The osmotic potential of polyethylene glycol 6000 . Plant Physiol. 51:914-916.

Nakayama, S., and M. Takabayashi. 1987. Germination characteristics of two paddy weed species of Ammannia genus. Weed Res. Jpn. 32(Suppl): 195-196.

NIER. 2001. Ammannia coccinea Rottb. In : An illustrated internet guide to alien plants in Korea. National Institute of Environmental Research. Inchon. Korea.

Panigrahi, S. G. 1980. Contribution of anatomy to the systematics of Ammannia. Phytomorphol. 30:320-330.

Prostko, E. P., H. I. Wu, J. M. Chandler and S. A. Senseman. 1997. Modeling weed emergence as influenced by burial depth using the FermiDirac distribution function. Weed Sci. 45:242248.

RDA. 2005. Ammannia coccinea Rottb. In : Exotic weed. National Institute of Agricultural Science and Technology, Rural Development Administration, Suwon, Korea.

Shen, X. R., S. W. Oh, H. R. Ryu and J. Y. Pyon. 2003. Germination and emergence of Ammannia multiflora Roxb. and its competition with rice. Kor. J. Weed Sci. 23(Suppl):267-276.

Shibayama, H. 2001. Weeds and weed management in rice production. Weed Biol. Manag. 1:53-60.

Streibig, J. C. 1980. Models for curve fitting herbicide dose response data. Acta Agric. Scan. 30:59-64. 